\title{
Using Psychoanalytically Oriented Psychotherapy with the Elderly
}

Mark D. Miller, MD

Thomas Jefferson University Hospital

Follow this and additional works at: https://jdc.jefferson.edu/jeffjpsychiatry

Part of the Psychiatry Commons

Let us know how access to this document benefits you

\section{Recommended Citation}

Miller, MD, Mark D. (1986) "Using Psychoanalytically Oriented Psychotherapy with the Elderly," Jefferson Journal of Psychiatry. Vol. 4 : Iss. 1 , Article 5.

DOI: https://doi.org/10.29046/JJP.004.1.002

Available at: https://jdc.jefferson.edu/jeffjpsychiatry/vol4/iss1/5

This Article is brought to you for free and open access by the Jefferson Digital Commons. The Jefferson Digital Commons is a service of Thomas Jefferson University's Center for Teaching and Learning (CTL). The Commons is a showcase for Jefferson books and journals, peer-reviewed scholarly publications, unique historical collections from the University archives, and teaching tools. The Jefferson Digital Commons allows researchers and interested readers anywhere in the world to learn about and keep up to date with Jefferson scholarship. This article has been accepted for inclusion in Jefferson Journal of Psychiatry by an authorized administrator of the Jefferson Digital Commons. For more information, please contact: JeffersonDigitalCommons@jefferson.edu. 


\title{
Using Psychoanalytically Oriented Psychotherapy with the Elderly
}

\author{
Mark D. Miller, M.D.
}

\section{INTRODUCTION}

Psychotherapy with the elderly, like geriatric medicine, has become a subject of renewed interest. This paper will review some pertinent aspects of the subject and hopefully dispel some myths. A case will be presented where psychoanalytically oriented psychotherapy was employed. In this case, forced termination was necessary after one year due to the therapist graduating from residency.

Sigmund Freud wrote: "Near or about the fifties, the elasticity of the mental processes, on which the treatment depends, is as a rule lacking. Old people are no longer educable" (1). Freud also cautioned that "the mass of material to be dealt with would prolong the course of treatment indefinitely..." (1), and further that: ". . . so much time would be required that the end of the cure would be reached at a period in life in which much importance is no longer attached to nervous health" (2).

Subsequent psychoanalytic writers have refuted this pessimistic outlook. Abraham described the successful analysis of four neurotic patients over 50 years of age and concluded that: "The age of the neurosis is more important than the age of the patient" (3). Jellifee, another early analyst, wrote: "Chronological, physiological, and psychological age do not go hand in hand" (4). Other psychoanalytic writers such as Grotjahn, Wayne, Meerloo, Weinberg, and Lawton stress the need for modified techniques in the elderly including a more supportive, active role for the therapist, more limited goals and, at times, direct intervention and environmental modification (5).

Martin Berezin has written extensively on the subject. He raises several noteworthy points. He reminds us that the intrapsychic ego operations are established early in life and once established become timeless and persist throughout life (6). The stereotype of rigidity as a barrier to psychotherapy in the elderly is a myth, Berezin notes, pointing out that a young rigid character type will be rigid in old age and conversely those who are more flexible will also be flexible in old age (6). Thus, character traits and the constellation of defenses

The author wishes to thank Drs. Abraham Freedman, Anita Schmukler, and Joan Devine for their excellent supervision, encouragement, and editorial help. Dr. Miller wrote this paper while a fourth-year resident at Thomas Jefferson University. 
must be assessed for each individual elderly patient just as one would do for a younger patient. Age, in itself, need not be a deterrent to explorative psychotherapy.

Many writings have outlined the losses that the elderly incur: losses of important relationships through death, losses of health, jobs, prestige, and societal respect in a youth oriented culture. The sum of these losses is usually but not always greater for the elderly. Berezin reminds us that the usual stereotype of an older person as weak, infirm, feeble, afflicted with memory defects, dependent and helpless, is a myth. He points out that less than $5 \%$ of those over 65 years of age require some degree of custodial care, a figure applicable throughout the world. Of the remaining 95\%, not all are, of course, mentally and physically healthy, but Berezin points out that most studies done on the elderly are skewed in that they were carried out in nursing homes or hospitals. This nonrepresentative body of literature, together with the commonly held belief that old age is a disease, has contributed to the prevalent gerontophobic attitude (6).

In that more losses have generally been sustained by the elderly, careful consideration must be given to the manner in which the elderly patient has adapted to these losses. Fenichel suggests that in difficult living situations or where the patient is physically ill or crippled, the neurosis itself may provide the best type of adjustment (7). Hollender also cautions: "When a person has turned to the past or developed fixed ways of doing things to derive narcissistic gratification or to protect against injuries to self-esteem, we should not tamper with these defenses unless we are sure that we can provide adequate substitutes for them" (8).

Another myth is that the elderly transferentially regard younger therapists as child surrogates. Dreams and patient associations reveal the opposite. Therapists are regarded as contemporaries, as mother or father figures or as any important life figure. Transference by definition is unreality, reminds Berezin; it is unconscious and not time oriented (6).

Countertransference, in many therapists who have difficulty dealing with the elderly, often reflects the therapist's own early and sometimes unresolved experiences in reacting toward his or her own parents or authority figures, writes Berezin. He further notes that a hostile defensive attitude on the part of the therapist is often managed by reaction formation or oversolicitation (6).

The question of whether it is "worth" investing time and money in psychotherapy with the elderly who are nearing the end of their lives is, for the author, best expressed by one of Berezin's patients who, when asked why she wanted psychotherapy, replied: "Doctor, all I have left is my future"” (6).

\section{THE CASE OF MRS. G.}

Mrs. G. is a 68-year-old widow of German background who presented to a crisis center with a chief complaint of being unable to "get over" her husband's death which 
occurred 22 years earlier. Her family doctor had sent her to a psychologist who concluded that she might need medication and she was referred to a crisis service. The initial interview revealed considerable personal grief over her husband's death of rheumatic valvular disease. She manifested obsessive, guilty rumination and described depression that had persisted for years, worsening at any of several anniversary dates, e.g. birthdays, the date of first meeting, wedding, the date her husband died, etc. Unable to support herself on her husband's pension, she went back to work for 12 years and had retired from that job six months prior to the evaluation. For years she described taking leave from her job as a clerk in a maternity unit to sequester herself in her apartment, hiding her depression from neighbors and family. The patient cited the ample time she now had to reflect (about the retirement her husband never had) as instrumental in her present suffering along with the awareness that she was now worse than usual, e.g. she noticed that she had "forgotten" the whole month of June (the anniversary of her husband's death) by dating her checks before and after. Her immediate concern was the question of whether she was losing her mind.

In the crisis center a diagnosis of major depression was made with a provisional diagnosis of unresolved grief reaction. The patient's concerns of going crazy were handled with supportive reassurance and the patient was encouraged to follow the recommendation for outpatient psychotherapy with appropriate medication.

The following day, the patient called and cancelled her appointment. Recontacting her by telephone revealed an intense negative transference. Mrs. G. stated that she did not feel that she could be helped, that I had seemed disinterested and condescending, and that I had implied that she was a crazy old lady who was ready for a "rubber room" and that I probably could not wait to terminate the interview to get back to my ball game. Having convinced her that we could only resolve these issues by meeting, we arranged for the first session.

Interestingly, although preoccupied with her husband's death, Mrs. G. spent the first 30 minutes talking about her father, an eccentric hypochondriacal man who was always tinkering with electrical gadgets and who was content to work for modest pay in a toy company instead of reaching his potential (as an engineer). The patient was the eldest of four female siblings and described a polarized family where father continually made unreasonable demands on the disgruntled women, e.g. installing a telephone from his bedroom to the kitchen so he could order food or self-selected remedies.

The patient was relieved that therapy was not as threatening as she had imagined and agreed to come twice a week. Due to her sleep disturbance, guilty ruminations and subjective dysphoria she was also begun on desipramine at $150 \mathrm{mg}$ nightly.

Further history unfolded over many sessions. Mrs. G. described her childhood as one of frustration and anger for being forced to assume many responsibilities at an early age. Many of these responsibilities, she felt, belonged to her father who relegated them to others or refused to be concerned about them. Mrs. G. recalled that, at age 12, she represented the family when inquiring about a house loan. She reported feeling embarrassed by the clerk asking her whether her silent father could speak English. Mother was described as an energetic, hard worker who was constantly serving her baked goods to visitors and who would tolerate her husband's eccentric ways saying: "What can you do?" When Mrs. G. was two years of age her father underwent an appendectomy and "recuperated" for the following four years under the care of his own mother and sisters in the home of his mother. Mrs. G. lived with her mother during that time in the home of her maternal grandparents and two uncles. Father would visit frequently during evenings 
over those years. Mrs. G. described this period with disdain, accusing her father of taking advantage of his illness to avoid work. The patient described many pleasant times with her grandfather and uncles. After the family reunited the other siblings were born leaving a six-year gap between Mrs. G. and her oldest sister. Mrs. G. described escaping to her grandparent's house many times during her childhood where she could again be the center of attention.

Mrs. G. recalled learning at an early age that her father had wanted a male child and recalled how he would enlist her help with electrical projects, e.g. sending her in narrow crawl spaces to splice wiring, etc. Although Mrs. G. related memories about her father with vehement criticism, she also spontaneously related several memories where he allowed her special privileges, e.g. presiding over tuning the crystal radio and the operation of the Christmas trains in his absence.

Illness was a theme that appeared repeatedly. Mrs. G. described her father's obsessions with his own "hanging stomach" for which he would convince a local doctor to pump out periodically. Her father was also obsessed with illness in his children. He would feel the foreheads of his sleeping children and awaken them for icepacks and coerce them to consume his home remedies. Mrs. G. felt that she often played nursemaid to her siblings and to her mother during "gall attacks" while often having her own symptoms overlooked by others. Rheumatic fever recurred in her husband after seven months of marriage with a lengthy convalescence and valvular compromise. Mrs. G. also described the miscarriage of her own first pregnancy, secondary to eclampsia with subsequent retroperitoneal abscess, several near fatal complications that necessitated a colostomy for two years and multiple subsequent surgeries over several years.

A striking feature in Mrs. G.'s presentation was the intensity of anger she showed toward various non-family members in her past, e.g. toward her daughter's teacher whom she felt unjustly scolded her daughter and to whom she responded by "laying her out purple." The extent of her expressed rage did not generalize to family members in her initial associations. The curious omission of this material about her husband in particular, her rigid descriptions of him as wonderful, and her guilty feelings that he died instead of her, suggested a dynamic formulation where reaction formation was used as a defense against repressed rage toward her dead husband. This formulation seemed to account for her pathological guilt and her inability to come to terms with her husband's death.

The therapeutic plan for this patient was to take every opportunity to point out her angry feelings that were rationalized away, denied or otherwise defended against, particularly those in reference to her husband.

Over the ensuing months Mrs. G. reported gradually realizing that she had "bottled up" her feelings for as long as she could remember. She frequently associated to her girlhood where she filled various responsible roles "without thinking about them." She would later admit that she resented them bitterly. Interpretations that raised the possibility of angry feelings toward her husband at first brought replies of staunch denial and litanies of her husband's merits and of his valiant struggle against illness. There seemed to be an aura of sacredness that would bring her to vehemently defend his honor whenever I or members of her family would speak of him.

Angry feelings were always expressed toward the therapist in retrospect. Mrs. G. would allude to how she felt I had dishonored her husband with the implications of my questions. Occasionally, insomnia or exacerbated colitis would occur in response to such angry feelings. 
Strong connective ties began to emerge in the early months between associations to her father and to her husband. Mrs. G. described them as opposites, with father being distant, self-centered and obstinate and with her husband as the ideal provider, husband, and father to her child. The associations that would follow such statements were to incidents that described her husband as every bit as obstinate as her father. Her reaction to the exploration of her feelings about her husband's obstinacy was to rationalize her anger with a gestured flap of the hand, stating: "What can you do anyway?" a phrase she recalled her mother often used toward her father's obstinacy.

Mrs. G. was unaware of the passive-aggressive nature of her behavior toward her husband. One anecdote involved her reciprocation for her husband's habit of bringing home sale items without consulting her. She bought him several pairs of shoes without his consent. To her dismay, the plan backfired and her husband thanked her for her consideration and exchanged them to suit his preference. A more pervasive pattern of passive aggression was evident under the umbrella of caring for her husband's health. Mrs. G. learned that her husband's heart was badly damaged during his second bout of rheumatic fever. She described, what her husband termed, "incessant nagging" about his failure to avoid certain foods, smoking, and overexertion for health reasons. Mrs. G. admitted quiet satisfaction when her husband required surgery for acute appendicitis after he refused to heed her warning that eating too much corn could cause such a malady. Mrs. G. also reported developing the habit of withholding news of daily household events from her husband. She recalled beginning the practice with the thought that unexpected news could precipitate heart failure in her husband's weakened condition. She once recalled reacting with intense rage when her brother-in-law telephoned her husband during dinner to tell him that their mutual brother had died. This practice of withholding household news became pervasive and would bring continual complaints from her husband that she treated him overcautiously. He complained of being unable to understand her rationale for deciding when it was a "good time" to tell him information; he would often find out through others before she would tell him.

With continued interpretation, clarification, and confrontation of these repeating themes, Mrs. G. made steady progress. Her sleep improved, her somatic complaints declined and she described feeling less depressed. The desipramine was tapered and stopped. Mrs. G. described feeling supported by the knowledge that others she had cautiously confided in had also benefitted from therapy. She felt encouraged by her ability to better handle holidays that had previously meant self-imposed isolation and guilty rumination. She related the comments of her daughter, family doctor and hairdresser who noticed changes in her. They described her as a different person, one more relaxed, and less stern and cynical. Mrs. G. no longer felt that her husband's death was her fault. She now felt that fate had dictated his death. She felt that if her husband's death was hastened by unheeded health recommendations it was his own fault for refusing to follow them since he stubbornly refused her warnings anyway. She described a desire to "get over" her grief for her husband, feeling that it had gone on too long. She attended sessions without fail, described "working over" every session on her own and reported that she was beginning to see that many of her feelings were linked to her past memories, many of them long forgotten.

Many feelings were worked through, particularly angry memories that had been previously rationalized away. In one instance she recalled feeling angry toward her father for relegating even his wife's funeral responsibilities to her. In another instance she 
recalled angry feelings toward her husband and "the doctors" for burying her stillborn first child before she arose from her delirium. She recalled anger toward her sister-in-law for commenting that her husband would probably still be alive had she been able to stop him from smoking.

During the tenth month of therapy, with an awareness of date of termination, Mrs. G began concentrating on the events of her husband's death. After many references to the support her husband offered her and the difficulties she experienced adjusting to his absence, the interpretation was made that she seemed angry toward her husband for leaving her. Mrs. G. first dismissed this idea as absurd, maintaining that "it wouldn't be right to be angry at a dead person who, after all, didn't ask to die."

The persistent refusal to permit anyone to help her with various struggles and her often stated fears of getting ill and becoming a burden on her family, in the context of references to the loss of her husband's support, suggested a defensive posture against dependent wishes. Mrs. G. seemed to have found the loving support in her husband that she felt was sorely lacking in her relationship to her father during her childhood. At the same time she was beginning to become more openly aware of the resentment she also felt toward her husband for the obstinate characteristics he shared with her father, and towards which she would outwardly respond with futile gestures.

With a backdrop of reworking the details of her husband's death, a real life wallet snatching produced reverberations in the therapy. Mrs. G.'s initial reaction was to withhold news of her loss from family members to avoid "rehashing it 90 times." Her rage persisted over several sessions with worsened insomnia and exacerbated colitis. Considerable ambivalence became clear over whether to tell me about it or not, fearing that I would think it was a fabricated story to avoid coming, thus saving money on her accumulated bill. Fearful that she would resort to avoiding the store where her wallet was stolen (as she had done to the store her husband died in), Mrs. G. forced herself to return. She described enduring muscles "as tense as ropes" and intense feelings of anxiety about a potential reunion with her suspect. She admitted that she feared she could lose control and hit him in the head with a can or "go down trying." Mrs. G. free associated to another purse she had lost at age seven, recalling anger toward her aunt for treating it insignificantly. It was clear that this incident had caused pervasive psychic turmoil beyond what would be reasonably expected. With further encouragement, Mrs. G. further associated to the loss of her stillborn child, to the loss of her uterus from early cervical cancer, and to the loss of her husband. The loss of the purse clearly had symbolic links to these other important losses in her life which could then be explored.

After reporting a conversation with a friend who described feeling angry at her husband for dying and leaving her, Mrs. G. admitted feeling angry toward me for implying that she may feel similarly. She then associated to an event six weeks after her husband's death where she screamed uncontrollably in her sleep such that family members summoned the family doctor. She recalled deciding not to tell the doctor that she regularly looked for her husband's image in the sky for fear that she would be "put away." Mrs. G. went on to describe how she and her husband and daughter would play games looking for animal shapes in the clouds and that her husband, an avid sky watcher, once said that she should look for him in the clouds when he was gone. Mrs. G. further associated to the trip to the hospital after receiving the telephone call that informed her that her husband was gravely ill. She stated that she "knew" he was dead but recalled telling her daughter, while enroute, that if he were to be an invalid she wished that he would die instead. When Mrs. G. was questioned about her feelings after her husband's 
death, she would automatically revert to describing the pain and grief she saw in others. She spoke of how her husband had suffered and how she felt she had been an added burden with her own illnesses. On repeated questioning she stated that she really did not know what she felt. She did not seem to recall having much feeling of any kind.

Subsequent sessions reiterated her anger toward me for "talking against her husband" and for my impending departure with "much still to do." Mrs. G. went on to recall her long held fear that her husband would die in the house and that she would somehow be blamed for taking away the "father of her daughter."

Having satisfied herself that I did not label her as crazy after confiding her cloud scanning vigil, she hesitatingly related that she sometimes talks to her husband by saying out loud things like "Well, what would you do in this situation?" She recalled feeling some security from the practice although she never really heard a reply, but she felt close to him. She further admitted sometimes faintly seeing him in the gray suit he was buried in, standing in the doorway before she went to sleep. She noted that he came more at times of turmoil and that he now came only infrequently.

Realizing that termination approached, Mrs. G. reviewed her reasons for seeking treatment. She recalled that she was having uncontrollable crying spells, sometimes while on the street. She recalled feeling that volunteering for therapy was the only alternative to being eventually "locked up and taken away." She admitted that she was terrified that I would suggest hospitalization and that she came to our initial sessions with her "claws up."

A particularly rich associational session involved Mrs. G.'s preoccupation with the story of the crucifixion of Christ. She hesitatingly admitted that since hearing the story read in second grade, she hoped that she had heard it incorrectly and that it would change by the following Easter season. Upon questioning, Mrs. G. reported that she could not stand the idea of anyone being punished and subsequently free associated to the whippings she received from her father. When encouraged to express her feelings on the matter, she rationalized her father's acts as understandable since his own father had been a cruel man who had once beaten a horse nearly to death for throwing its rider. Her grandfather reportedly only escaped hanging for such an offense during that era by virtue of his political connections. Mrs. G. further associated to the funeral of a female classmate, also in the second grade. Mrs. G. was picked to participate in the funeral procession, stating that: "We probably didn't know what was happening but (on second thought) maybe that's why I have problems with funerals." This material was used to formulate interpretations suggesting that she may have had retaliatory fantasies toward her father by beating or even death (like her paternal grandfather deserved for beating a horse). Her associations to the girl's funeral revealed her unconscious guilt for having such fantasies through identification with the dead girl. Mrs. G. expressed relief after discussing these interpretations and further associated to pleasant evenings with her maternal grandfather and uncles. She recalled the pleasurable aroma of peeled apples and sips of their beer. She recalled an incident where she had carved her initials into her grandfather's new chair. Her father was enraged but was thwarted in his attempt to punish her by her grandfather. Her uncles were amused by the incident which indicated to them that she felt she was part owner of the chair. She further recalled that she considered her father merely a frequent visitor. Her most clear early memory of him was on "moving day" when she was abruptly returned to living with her father at age six. Mrs. G. seemed surprised by her own realization that she must not have wanted to go.

A parallel theme throughout the therapy was Mrs. G.'s relationship with her 
daughter who was now married with several children. She admitted, in retrospect, to visiting her daughter largely out of a sense of duty, feeling anxious to leave during visits and withholding bad news or personal hardship from her daughter and family so as not to bother them. She described feeling tense and unable to enjoy herself at family functions particularly during holidays. She implied angry feelings for having sacrificed her vacations to help out with the births of her grandchildren. Mrs. G. recalled how her husband would go to his daughter immediately after work. She described how they did projects together and how they referred to each as "best pals." She recalled how guilty her husband felt for impulsively spanking their daughter for riding her bicycle in traffic. Gradually a picture of jealousy emerged toward her daughter for her intimacy with the patient's husband. The scenario she witnessed was much like the one she had hoped for with her own father. Interpretations along these lines were made when appropriate. Gradually, over the course of therapy, Mrs. G. described increased rapport with her daughter, often via her grandchildren whom she enjoyed greatly. She described having fun bantering with them and reported having entered the pool with them for the first time. She reported anticipating pleasure in upcoming family functions and also a lack of guilt for refusing to go if she wasn't feeling up to it.

Two weeks prior to termination, Mrs. G.'s hair was noted to have changed color. She reported that she had wanted to change it for 14 years, but had not done so out of fear that onlookers would think that she was trying to be seductive. She now stated that she did not care what anyone thought. She described feeling good about herself and wanted to do the things that she liked in her remaining years. She was very concerned about what I got out of this therapy and admitted that she had dyed her hair before I left so that I would be sure to see evidence of the changes that had taken place in her.

Termination brought concerns over a potential relapse, feelings of unwillingness to "go through this again" with another therapist, and also a sense that she now knew she could benefit from therapy if needed again in the future.

\section{DISCUSSION}

This patient had been treated for years with high dose Valium ${ }^{\circledR}$ and narcotic analgesics for insomnia and various pains. In that this patient described abruptly stopping these medications prior to our initial visit, some withdrawal effects no doubt contributed to her presenting psychic distress. The initial evaluation produced a diagnosis of Major Depression with an unusually protracted grief reaction. A view of this patient as a retired older woman who now had time to reflect on her losses and who then became depressed seemed reasonable, but would have missed the depth and breadth of neurotic conflicts that led to her finally initiating treatment. Much of her rage was unknown or unclear to her consciousness at the onset of treatment. She knew it was "wrong" to grieve so long but she did not know why or how to remedy it. Needing a psychiatrist meant confirming long held fears that she might be crazy like her eccentric father whom she felt she had inherited many traits from. Understanding this woman's conflicts over her husband's death clearly required consideration of the connections between her feelings toward her father and her husband, and the confrontation of her defenses against rage. 
Although this therapy was limited to one year, this patient's progress was considerable. From a life pattern of sequestering herself in silent, guilty suffering on myriads of anniversaries connected to her dead husband, Mrs. G. progressed to her present ability to enjoy her life and family and to share her negative as well as positive thoughts with others. Mrs. G. now seems more comfortable with ambivalent feelings and is no longer obsessed with her husband and his death.

Franklin Maleson (personal communication) makes the analogy comparing the process of psychotherapy to breaking up a logjam (of feelings and defenses against them) thereby restoring movement (growth). Given this patient's progress in one year, this analogy seems particularly apt.

\section{CONCLUSION}

This case illustrates the contribution of character traits in determining the outcome of therapy. Mrs. G. was able to use insight and apply it on her own to conflicted feelings she noted outside of therapy. Her open mindedness, curiosity, and willingness to explore along with some obsessional character traits, allowed the therapy to progress to a deeper level of understanding.

In conclusion, psychodynamic psychotherapy with the elderly, like psychotherapy with anyone, must be based on an assessment of the individual. Hopefully, this paper has illustrated that the tendency to stereotype the elderly as less appropriate for psychodynamic psychotherapy is a myth.

\section{REFERENCES}

1. Freud S: On psychotherapy. Standard Edition VII:255-268, 1905

2. Freud S: Sexuality in the aetiology of the neurosis. Standard Edition III:259-286, 1898

3. Abraham K: The applicability of psychoanalysis to patients of advanced age, in Selected Papers of Psychoanalysis. London, Hogarth Press, 1949

4. Jellifee SE: The old age factor in psychoanalytic-psychotherapy. Med J Rec 121:7-12, 1925

5. Rechtschaffen A: Psychotherapy with geriatric patients: a review of the literature. $J$ Gerontology 73:45-61, 1959

6. Berezin M: Psychodynamic considerations of aging and the aged: an overview. Am J Psychiatry 128:33-41, 1972

7. Fenichel O: The Psychoanalytic Theory of Neurosis. New York, Norton, 1945

8. Hollender MH: Individualizing the aged. Soc Casework 33:337-342, 1952 